\title{
Impact of Climate Change on Metal and Suspended Sediment Concentrations in Urban Waters
}

\author{
Paul Frogner-Kockum ${ }^{1 *}$, Gunnel Göransson ${ }^{2}$ and Marie Haeger-Eugensson ${ }^{3,4}$ \\ ${ }^{1}$ Department for Management of Contaminated Sites, Swedish Geotechnical Institute, Malmö, Sweden, ${ }^{2}$ Department of \\ Geotechnical Risk and Climate Adaptation, Swedish Geotechnical Institute, Gothenburg, Sweden, ${ }^{3}$ Department of Earth \\ Sciences, Gothenburg University, Gothenburg, Sweden, ${ }^{4}$ COWI AB, Gothenburg, Sweden
}

In order to study the impact of climate change on metal contaminant transport in urban waters and its relevance for water quality, we have analyzed variations in metal- and suspended sediment concentrations (SSC) in three urban rivers and one small creek in the Gothenburg region during various hydrological events such as spring flood, dry period, and wet period. To interpret river loads of metals and SSC we have furthermore followed meteorological trends since 1961 and additionally calculated future trends for the Gothenburg region, located on the west coast of Sweden. During periods of a short-term increase in precipitation we found an increased particle bound metal transport in urban watercourses of the Göta Älv River. In addition, a correlation between studied parameters indicates that surface runoff from brownfields most likely is the main source to the increased transport of pollutants in river systems rather than re-suspension of polluted river sediment.

Keywords: climate, precipitation, runoff, rivers, metals

\section{INTRODUCTION}

\section{Global Climate Change, Extreme Weather Events, and Urban Water Quality}

There has been an increase of $\mathrm{CO}_{2}$ in the atmosphere since, at least, the beginning of the monitoring of atmospheric $\mathrm{CO}_{2}$ in the 1950s (Keeling and Whorf, 1999; Frogner et al., 2001). Together with other climate gasses this has resulted in the climate change seen as, among other things, increase in severity and frequency of extreme weather events such as elevated temperatures, cyclones and heavy rainfall which may influence water quantity and quality (Khan et al., 2015).

In addition to such extreme weather events, $\mathrm{WHO}$ also predicts changed patterns of disease and negative effects on agricultural production due to climate change. All these factors taken together, events induced by global climate change are estimated to cause over 150,000 deaths annually (World Health Organization, 2020).

Simultaneously, the ongoing worldwide urbanization process with population growth, migration and the rapidly growing number of mega-cities poses its own challenge for safe drinking water (Larsen et al., 2016). The emerging challenges for the availability of clean drinking water have great public health significance as they pose severe threats to human health (Chowdhury et al., 2016). There is already today a number of urban environmental challenges from e.g., air, water and soil contaminants in addition to the increasing effect of climate change. In order to take relevant and forward-looking measures, that are to be implemented in 
national, regional and global policies, it is important to improve the insight to the environmental processes that may be caused by climate change.

A variety of heavy metals are continuously emitted in urban areas for example from traffic, combustion, various building and road materials, leakage, and spills of chemicals, and the release of untreated waste waters. These metal contaminants are further transported by air, surface runoffs and groundwater flow and lead to the contamination of urban waters that influence the drinking water quality and thereby threatens urban health (Chowdhury et al., 2016).

\section{Climate Impact on Metal Contaminant Transport}

The impact of climate change on river water quality has been studied by several authors (Tu, 2009; Bae, 2013; Fan and Shibata, 2015; Xia et al., 2015; Rostami et al., 2018). Some of these studies have focused on impact of temperature on water quality and others on the consequences of surface runoff. These works suggest that climate change have both a direct and indirect effect on surface water quality. For instance, the impact of raising temperature as a direct consequence of climate change due to increased atmospheric $\mathrm{CO}_{2}$ levels (Frogner, 1998; Whitehead et al., 2009; Benítez-Gilabert et al., 2010; Prathumratana et al., 2011) which indirectly increase chemical weathering (due to both temperature and lower $\mathrm{pH}$ ) leading to the release of metals in the earth crust and soils. On the other hand, precipitation has an impact on surface runoff, river discharge, and thus indirectly on the river water quality. Surface runoff is an important carrier of contaminants from the surrounding land (brownfields) to the receiving surface water. The consequences of these effects are leading to a degradation in water and sediment quality that will impact negatively on human health and the ecosystem. The linkage between surface water quality and precipitation seems to be more evident during heavy rainfalls (Rostami et al., 2018). These observations argue for further studies on how changes in meteorological conditions can affect water quality and the management of watercourses as a source of drinking water supply.

\section{Consequences of Climate Change on Urban Water Quality}

Metal contaminants in surface runoff ultimately end up in fresh water inlets of rivers but also in coastal waters (Visser et al., 2012) that may counteract sustainable urban development and human health. To retain a sustainable and healthy urban water cycle it has become important to understand how metal transportation pathways may negatively impact on water quality (SemadeviDavies et al., 2008; Wilson and Weng, 2011; Astaraie-Imani et al., 2012; Mouri et al., 2012; Crossman et al., 2013; Islam et al., 2015).

So far, the negative consequences of climate changes like flooding on urban development are well-recognized (Dankers and Feyen, 2009; Pall et al., 2011; Schiermaier, 2011), while implications of increased precipitation on contaminant transport and degrading water quality are still under debate (Sangel de Oliviera and Cavalcanti de Cunha, 2014; Boehlert et al., 2015;
Rostami et al., 2018). Whitehead et al. (2009) reviewed the potential impact of climate change on surface water quality and concluded that there are uncertainties regarding the connection between precipitation quantities and urban water quality. The effect of climate change on groundwater quality, recharge processes and the interaction with surface water for both different land-use as well as hydrological settings still seems to be lacking (Kløve et al., 2014). Additionally, information is also lacking regarding the connection between urban groundwater and river water quality (Rivett et al., 2011), even though it is well-recognized that urban groundwater quality is affected by infiltration of storm-water, wastewater leakage, and spills as well as leakages from point sources (Navarro and Cabonell, 2007; Lerner and Harris, 2009; Rivett et al., 2011; Wang et al., 2012).

\section{Climate Scenarios for Northern Europe}

Climate projections for Northern Europe include more wet winters and drier summers due to increased greenhouse gas concentrations in the atmosphere. Precipitation has increased from Iceland to Scandinavia (Hurrell et al., 2003) and an increased cyclone count over the Northern Atlantic and Western Europe results in more precipitation (Ulbrich et al., 2009; Rajczak and Schär, 2017). A similar pattern is evident trough modeling future precipitation patterns for 2080 which suggest a pronounced increase in precipitation from northern Great Britain to the west coast of Sweden (McDonald, 2011) and a similar pattern was also seen in later modeling experiments with higher resolution from regional downscaling also with confirmed measurement trends (Christensen et al., 2019). For Sweden, the estimated annual increase of precipitation is about 15-35\% from 1961 until 2100 depending on the RCP 4.5 and RCP 8.5 scenarios respectively, and in some areas even up to $40 \%$. For the Gothenburg area, SW Sweden, annual mean precipitation is estimated to increase at least $10-30 \%$ (RCP 4.5, respectively, RCP 8.5) from 1962 until 2100, with the largest increase during winter and spring (SMHI, 2020). Representative Concentration Pathway (RCP) stands for future climate scenarios, all of which are considered possible depending on the volume of greenhouse gases (GHG) emitted in the years to come. Four different pathways RCP2.6, RCP4.5, RCP6, and RCP8.5 were proposed by IPCC in the fifth Assessment Report (AR5) in 2014.

\section{Aim and Objectives}

The aim of this study was to assess the potential impact of climate change on urban water quality in the Gothenburg area, SW Sweden. We evaluated how climatological parameters such as dry and wet periods as well as spring flood events affected groundwater levels, discharge and metal contaminant transport.

The results of our study will hopefully provide decision makers with increased knowledge to develop future measures for improving urban water quality and consequently for securing safe drinking water.

The results will also contribute to the knowledge platform required to be able to take relevant measures to be able to avoid the spread of pollution caused by a changing climate. This is especially important for rapidly urbanizing areas in countries that 


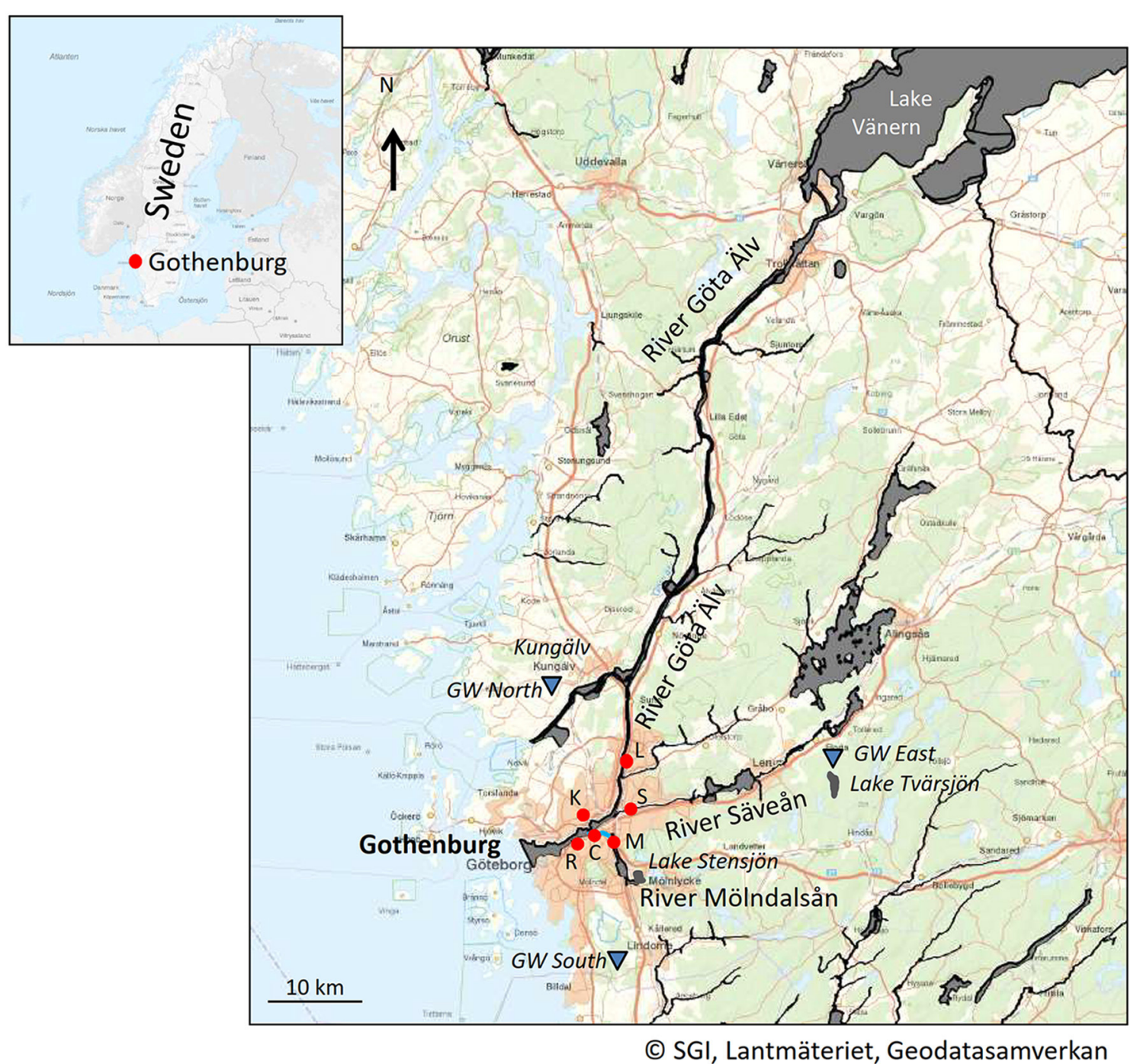

FIGURE 1 | City of Gothenburg, Sweden, showing the sampling sites for surface water sampling, the lakes Tvärsjön and Stensjön, and three groundwater monitoring wells. Sampling site L, Lärjeholm; S, Säveån; M, Mölndalsån; K, Kvillebäcken; C, City Canal; R, Röda Sten. ๑ SGI, Lantmäteriet, Geodatasamverkan.

are challenged by fast changing demographic changes and the emerging trend of megacities.

\section{MATERIALS AND METHODS}

\section{Study Area}

The study area includes the city of Gothenburg in Sweden and the rivers Göta Älv, Säveån and Mölndalsån, and the small creek Kvillebäcken (Figure $\mathbf{1}$ and Table 1). Gothenburg is the second largest city in Sweden with almost 580,000 inhabitants. The city has a history of shipbuilding but since these operations were closed down other business have grown strong, such as the techindustry and the service sector. The vision is for the city to grow by a third by the year 2035 .

The river Göta Älv is the main river that runs from Lake Vänern to the estuary, through the Gothenburg city center and the harbor (see Figure 1). Close to the town Kungälv, the river divides into two branches where the southern branch is still referred to as Göta Älv. The river is regulated by three hydropower stations and the fluctuating energy demands combined with the regulated outflow from Lake Vänern govern the flow in the river Göta Älv (Göransson et al., 2013). The areas surrounding the river before it reaches the Gothenburg city, are pasture land, forests, bedrock, and small urban areas. The river is the recipient of treated wastewater and serves as the drinking water supply for about 700,000 inhabitants.

The water quality upstream from Gothenburg is primarily affected by direct runoff from urban, rural, and livestock areas, wastewater from urban areas, combined sewer overflow during heavy rainfall ( $₫$ ström et al., 2007), leakage from contaminated sites, and accidental spills from industries and vessels. Both the rivers Säveån and Mölndalsån flow through several lakes and are 
TABLE 1 | Description of the sampling sites.

\begin{tabular}{|c|c|c|c|c|c|c|c|}
\hline Sampling site & Type & Description & Sampling point & $\begin{array}{l}\text { Sampling depth } \\
\text { ( } m \text { below water table) }\end{array}$ & $\begin{array}{l}\text { Average } \\
\text { discharge }\end{array}$ & Catchment & Subcatchment \\
\hline $\begin{array}{l}\text { Lärjeholm, Göta } \\
\text { Älv River }\end{array}$ & $\begin{array}{l}\text { Rural } \\
\text { Upstream }\end{array}$ & $\begin{array}{l}\text { Main river Göta Älv, } \\
\text { upstream Gothenburg City, } \\
\text { at the raw water intake }\end{array}$ & $\begin{array}{l}\text { Small jetty next to the } \\
\text { raw water intake }\end{array}$ & $2 m$ & $190 \mathrm{~m}^{3} / \mathrm{s}$ & $\begin{array}{l}48,966 \\
\mathrm{~km}^{2}\end{array}$ & $29,585 \mathrm{~km}^{2}$ \\
\hline Säveån River & $\begin{array}{l}\text { Urban } \\
\text { City }\end{array}$ & $\begin{array}{l}\text { Near its inflow into Göta Älv } \\
\text { River }\end{array}$ & Kodammsbron bridge & $2 m$ & $24 \mathrm{~m}^{3} / \mathrm{s}$ & $1,481 \mathrm{~km}^{2}$ & $12.2 \mathrm{~km}^{2}$ \\
\hline Kvillebäcken & Urban & $\begin{array}{l}\text { A small creek in the } \\
\text { northern part of the city, } \\
\text { entering the northern side of } \\
\text { the River Göta Älv }\end{array}$ & $\begin{array}{l}\text { 200 m upstream the } \\
\text { outflow into River Göta } \\
\text { Älv }\end{array}$ & $0.5 \mathrm{~m}$ (very shallow creek) & $0.3 \mathrm{~m}^{3} / \mathrm{s}$ & $15.9 \mathrm{~km}^{2}$ & $15.9 \mathrm{~km}^{2}$ \\
\hline City Canal & $\begin{array}{l}\text { Urban } \\
\text { City center } \\
\text { Harbor }\end{array}$ & $\begin{array}{l}\text { The part of Mölndalsån river } \\
\text { that runs through the city } \\
\text { center }\end{array}$ & Residensbron bridge & $2 m$ & $0.2 \mathrm{~m}^{3} / \mathrm{s}$ & $8.6 \mathrm{~km}^{2}$ & $8.6 \mathrm{~km}^{2}$ \\
\hline
\end{tabular}

Catchment size and discharge data retrieved from https://vattenwebb.smhi.se/modelarea/.

surrounded by pasture land, forests, and minor urban areas. The most downstream parts hide old contaminated land from former industrial activities. The rivers Säveån and Mölndalsån connect to the River Göta Älv in the Gothenburg city center. Kvillebäcken creek flows from a nature area and through a residential area (former industrial area) before its confluences with the River Göta Älv, in Gothenburg city.

In the harbor area and the estuary, freshwater meets seawater developing a salt water wedge that occasionally reaches the fresh water intake $8 \mathrm{~km}$ upstream of the city center. The location of the salt water wedge depends on wind speed and direction, high/low pressure, and the river flow. Rising sea level, storm surges, heavy rain, and heat waves, are the effects of climate change that the municipality has been experiencing since the late 1990s.

\section{Water Sample Collection}

In this study, variations in concentrations of metals and suspended sediment concentrations (SSC) were analyzed for three urban rivers at 5 locations (Figure 1). Water samples were collected using a metal free Hydro-Xm water sampler, that holds $1.7 \mathrm{~L}$ water. The water sampler is based on the Ruttner design, which is a handy and robust instrument to collect water samples vertically at any depth. The sampler consists of a transparent cylinder that is opened in both ends, with two lids at each end that are held apart from the openings by a rod placed through the cylinder. A wire with a weight is placed at the bottom of the cylinder to improve vertically deployment. A long wire with depth markings, and a weight that can slide along the wire, is attached to the top of the cylinder. The sampler is slowly deployed through the water column until the desired depth reached. The user then drops the weight and when it hits the lid of the cylinder a closing mechanism is triggered and the water from that specific depths is captured inside the cylinder.
The water is retrieved via a tap located on the bottom plug. A hose is attached to the tap to facilitate water collection in a laboratory bottle.

Before sampling, the sampler was rinsed a couple of times with water from the sampling site, to avoid cross-contamination between sites.

The water bottles for chemical analyses, as well as filters and syringes, were retrieved from the accredited laboratory ALS Scandinavia. Bottles aimed for metal analyses were used. After sampling, the water samples were stored cooled until transport to the laboratory the same day as the samples were taken. Both infiltrated and filtrated water samples were sent to the laboratory. Filtration was done in the field. Duplicate samples were taken, one of which was analyzed and the other was saved for possible later analysis. Physical parameters (temperature, $\mathrm{pH}$, conductivity, and redox) were analyzed in the field using a YSI 600 water sound.

The sampling sites are shown in Figure $\mathbf{1}$ and are further described in Table 1. To establish the meteorological effects on water quality fluctuations, we collected water samples during one season to cover a spring flood (April 6, 2010), a period with almost no rain (June 17, 2010) and a period with almost constant rain (August 25, 2010). These occasions are hereafter named: Spring flood, Dry period, and Wet period, respectively. Furthermore, we carried out Spring flood sampling at the end of the spring flood period. The period represents a period with snowmelt, little rain, and partly water saturated-partly frozen ground. The limited number of sampling campaigns can be partly compensated by the fact that sampling took place in several watercourses at the same time.

Dry and Wet period sampling were done at the beginning and the end of the summer season. Dry period samples were taken 
TABLE 2 | Weather conditions during each of the sampling campaigns.

\begin{tabular}{|c|c|c|c|}
\hline Description & Spring flood & Dry period & Wet period \\
\hline Mean air temp. & $5^{\circ} \mathrm{C}$ & $14^{\circ} \mathrm{C}$ & $14^{\circ} \mathrm{C}$ \\
\hline Mean water temp. & $3-4^{\circ} \mathrm{C}$ & $15.5-16.5^{\circ} \mathrm{C}$ & $16^{\circ} \mathrm{C}$ \\
\hline Mean wind direction & South & South & West \\
\hline Mean wind speed & $<7 \mathrm{~m} / \mathrm{s}$ & $<7 \mathrm{~m} / \mathrm{s}$ & $9 \mathrm{~m} / \mathrm{s}$ \\
\hline Weather conditions & Foggy in the morning, dizzy at lunch time & Sunny, dry & Windy, no rain the sampling day \\
\hline Mean river flows & $216^{a}, 36^{b}, 7.9^{c} \mathrm{~m}^{3} / \mathrm{s}$ & $155^{\mathrm{a}}, 17^{\mathrm{b}}, 1.4^{\mathrm{c}} \mathrm{m}^{3} / \mathrm{s}$ & $141^{\mathrm{a}}, 27^{\mathrm{b}}, 4.5^{\mathrm{c}} \mathrm{m}^{3} / \mathrm{s}$ \\
\hline Accumulated precipitation (30 days) & $65.1 \mathrm{~mm}$ & $44.3 \mathrm{~mm}$ & $201.6 \mathrm{~mm}$ \\
\hline
\end{tabular}

in June and represented lower stream flows, lowered GWL and no surface runoff. Wet period sampling took place in August and represented high stream flows, raised GWL and surface runoffs, although not first flush. We avoided sampling during first flush as it is known to yield elevated concentrations. The purpose was instead to catch the impact from shallow groundwater flows and water saturated soil.

The sampling sites at these rivers represent different contaminant dispersion pathways and environments. Sampling site Lärjeholm (Göta Älv) represents the main river and its inflow to the Gothenburg city from a non-urban environment. This sampling site is located at the raw water intake for the fresh water supply. Sampling site Mölndalsån represents a minor inflow from an urban environmental area to Gothenburg. Sampling site Säveån also represents a minor inflow but from a modern industrial area. Sampling site Kvillebäcken represents a small stream in a formerly industrialized, but now residential area. Sampling site City Canal represents the Gothenburg city center. Finally, sampling site Röda Sten (Göta Älv) represents the Göta Älv River outflow to the estuary and the sea. Water samples were taken 1-3 m below the water surface depending on river depths (see Table 1). The Röda Sten, the City Canal, and Kvillebäcken sampling sites, located in the vicinity of the harbor, are more affected by sea water than the other sites. During the Wet period sampling campaign, river discharges were high at the same time as the westerly winds pushed sea water upstream. No samples were taken in Kvillebäcken creek during the Dry period, as the flow direction was the other way because of a combination of the effect of the sea level and too low water flow in the creek.

The weather conditions for each of the sampling campaigns are shown in Table 2. For the Göta Älv River, discharges are measured at the hydropower stations and flow data are available through contact with the energy company. River flow data for Säveån and Mölndalsån are available as modeled data and can be downloaded from the Swedish Meteorological and Hydrological Institute's (SMHI) web (https://www.smhi.se). The same goes for precipitation data. Groundwater data can be downloaded from the Swedish Geological Survey's (SGU) web (https://www.sgu.se). Most data are available as daily averages.

\section{Water Analyses}

Metals were analyzed as dissolved and particle bound concentrations. Separation was done in the field and using $0.45 \mu \mathrm{m}$ filters, and metals were analyzed both on filtered water samples and on particles trapped on filters. The dissolved phase corresponds to the sample after filtration but may include some colloid bound metals as due to the filter size. Analyses were performed by the accredited laboratory ALS Scandinavia. Metals were analyzed according to modified EPA methods 200.7 (ICP-AES) and 200.8 (ICP-SFMS) (see further EPA, 1994, 1997). Dissolution took place with a microwave oven in closed Teflon containers with $\mathrm{HNO} 3$ / H2O2. Determination of suspended solids were done by filtration through glass fiber filters according to Swedish Standard SS EN 872. We also used field measurements and analysis conducted by the Water Conservation Associations for the rivers Göta Älv, Mölndalsån and Säveån to determine pH, conductivity, and water temperatures.

\section{Precipitation, Discharge, and Ground Water Levels}

Based on available measurements from 1961 to 2010 from 10 meteorological stations in and around Gothenburg, we calculated the total, average and maximum precipitation. The GWL were performed at three locations (north, east, and south of the city, see Figure 1). The precipitation was related to precipitation during a standard normal year SNY (1961-1990) and to future predictions based on modeled data in a grid resolution of $50 \times$ $50 \mathrm{~km}$ (climate data available at https://www.smhi.se). To enable a comparison between measured and calculated precipitation, all stations within the chosen model grid were averaged. We performed analyses based on measured yearly means of total precipitation from all five sites within the area. As available information of discharges of sampled rivers only dates back to 1999, we analyzed long-time trends in the area based on two other smaller rivers (upstream from Mölndalsån and Säveån is Stensjön and Tvärsjön, respectively), using daily means from 1940 and 1960 (see Figure 1 for location). The effect of changed precipitation in these rivers is assumed to be similar to the larger rivers Mölndalsån and Säveån.

\section{RESULTS}

\section{Hydrological Conditions During the Sampling Campaigns}

In Figure 2 the accumulated precipitation and the river discharges during different sampling occasions are shown. The vertical lines denote the three sampling occasions. Before 


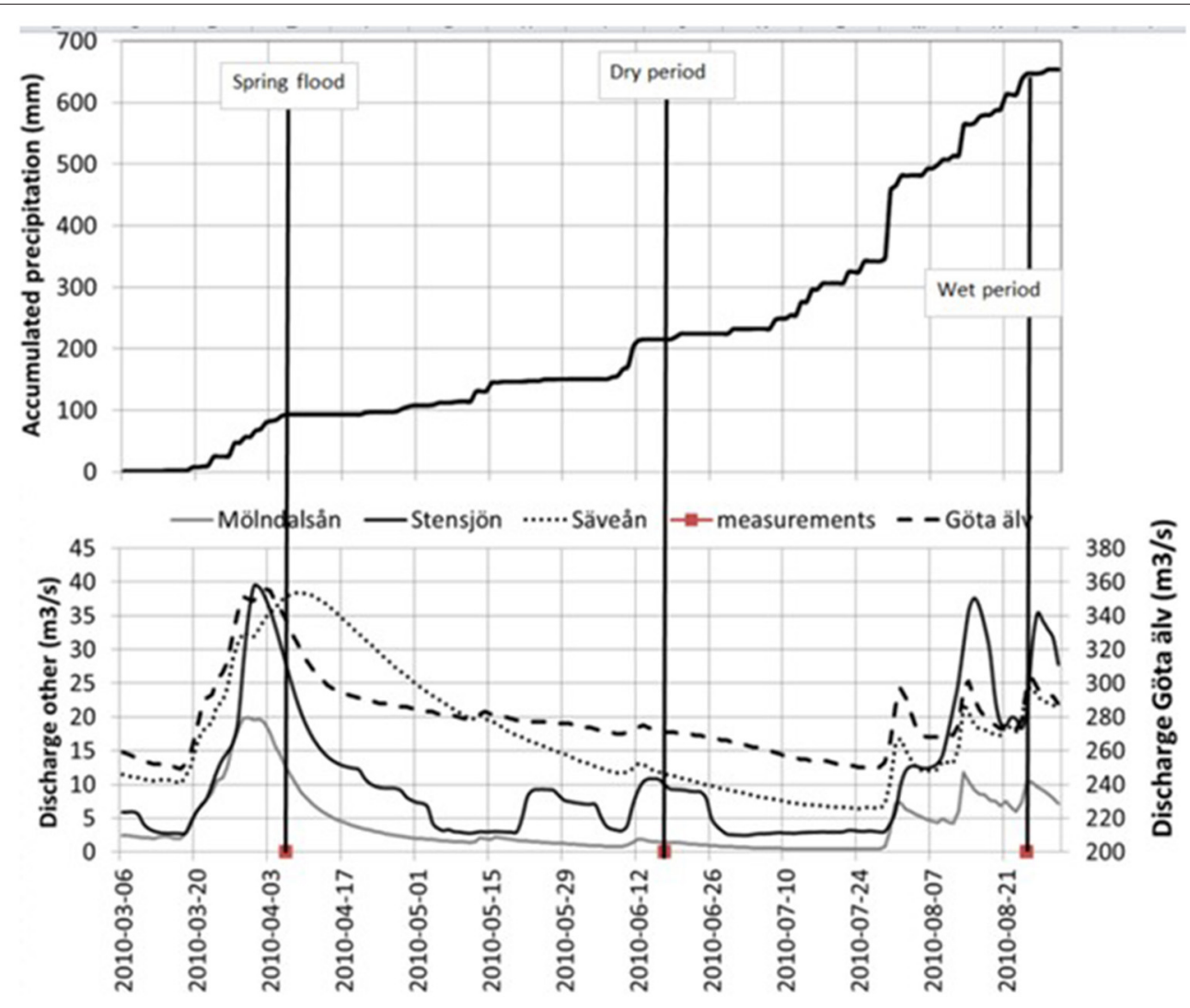

FIGURE 2 | Accumulated precipitation in Gothenburg (Top). Discharge (Bottom) in different rivers during the same period. Discharge from Stensjön is based on measurements and the others on modeling (Hype model). The River Göta Älv data is plotted on the right y-axis.

the Spring flood sampling campaign, precipitation occurred occasionally but since the ground was still frozen after a cool winter, the discharge became higher than normal for this period. Prior to the Dry period sampling campaign, there were more than 2 months with few precipitation occasions which resulted in low discharge. The Wet period sampling campaign occurred with about one and a half months of continuous rain which yielded a steady increase in discharge in all rivers. According to data in Figure 2, the discharges in Mölndalsån and Stensjön had a faster response with the first flow peak happening nearly simultaneously as the rainfall. There was a delayed peak in Säveån, which coincided with the measurement occasion of the spring flood sampling campaign.

The groundwater level was also recorded for the time range shown in Figure 2. The groundwater level was about $0.75 \mathrm{~m}$ below the ground during the spring flood in April but fell to $1.2 \mathrm{~m}$ below the ground during the dry period in mid-June. During the wet period at the end of August, the groundwater level increased again to about $0.6 \mathrm{~m}$ below ground level. We found that the groundwater level during the sampling occasions were even higher than the 30 years mean summer levels for the Spring flood and the Wet period sampling campaign, but about the same for the Dry period sampling campaign. The field instrument for the measurement of physical parameters showed unstable and, in some cases, unrealistic results. Instead, we used measurements of $\mathrm{pH}$ and conductivity conducted by the Water Conservation Associations for the rivers Göta Älv, Mölndalsån, and Säveån (Göta älvs vattenvårdsförbund, 2010). The results show a stable $\mathrm{pH}$ around 7 ( $\mathrm{pH} 7.2-7.5)$ during the year and in all three rivers. Furthermore, their measurements show a general increase in conductivity the closer you get to the sea which indicates some mixing of seawater.

\section{Levels of Suspended Sediment Concentrations in Rivers}

Measured SSC concentrations are shown in Figure 3. We found an increase in SSC for the Wet period compared to the other two periods. In Mölndalsån and Säveån there was a similar relation in SSC between the Spring flood, Dry period, and Wet period, and a similar relation between the mentioned periods was also found at the outflow of Göta Älv (Röda Sten and the City Canal). However, at Lärjeholm (River Göta Älv, upstream of Gothenburg city), highest SCC was found during the Dry period sampling campaign.

\section{Levels of Metals}

Total concentrations of $\mathrm{Cr}, \mathrm{Cu}, \mathrm{Pb}$, and $\mathrm{Zn}$ are shown in Figure 4. In general, highest concentration were found in samples taken 


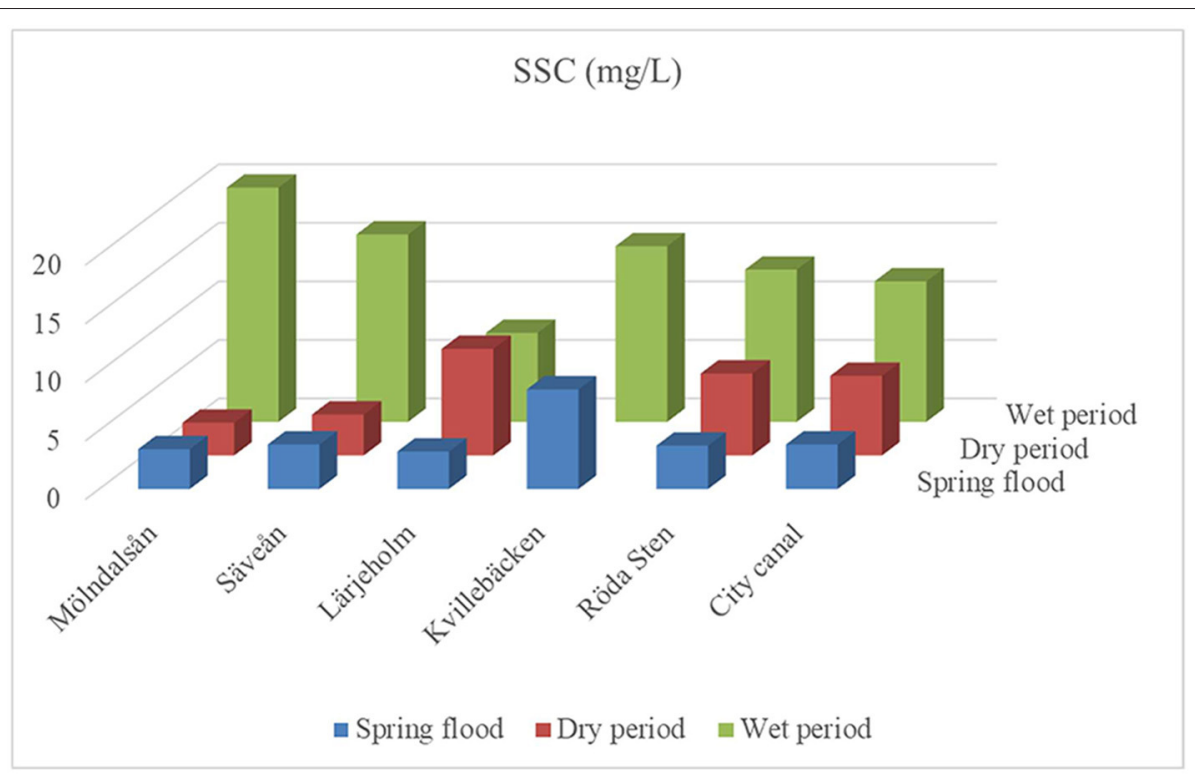

FIGURE 3 | Suspended sediment concentration (SSC) at each sampling sites and the three sampling campaigns.

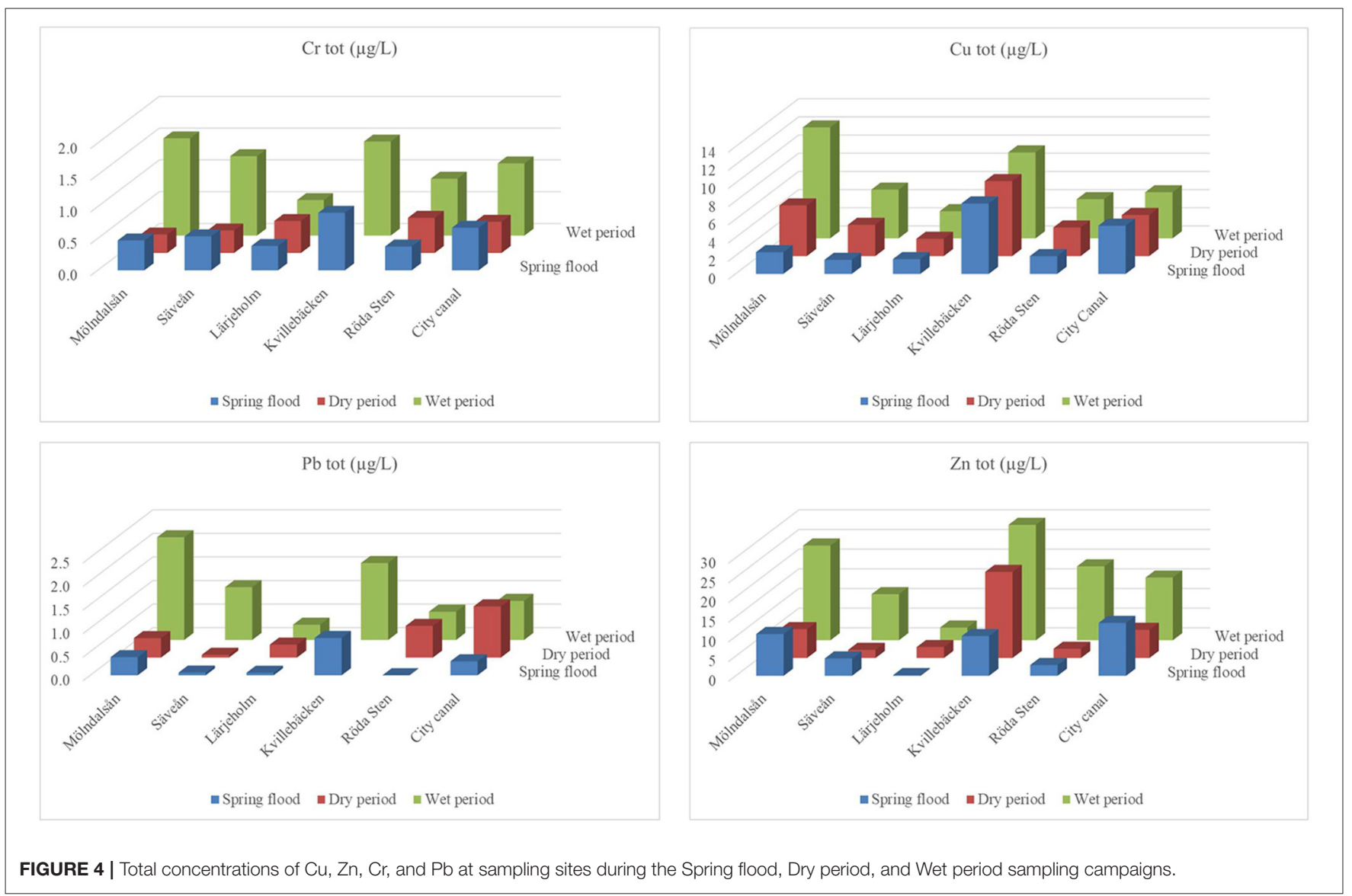

during the Wet period, but there is a deviation with respect to $\mathrm{Cu}$ and $\mathrm{Pb}$ at the sampling sites City Canal, respectively, Röda Sten, that showed highest concentration of $\mathrm{Cu}$ during the Spring flood and highest concentration of $\mathrm{Pb}$ during the Dry period.
Figure 5 show $\mathrm{Cr}, \mathrm{Cu}, \mathrm{Pb}$ and $\mathrm{Zn}$ as particle bound concentrations and in Figure 6 as dissolved metals. The distribution between particle bound and dissolved phases (of the total content) varies with metal. The particle bound fraction 

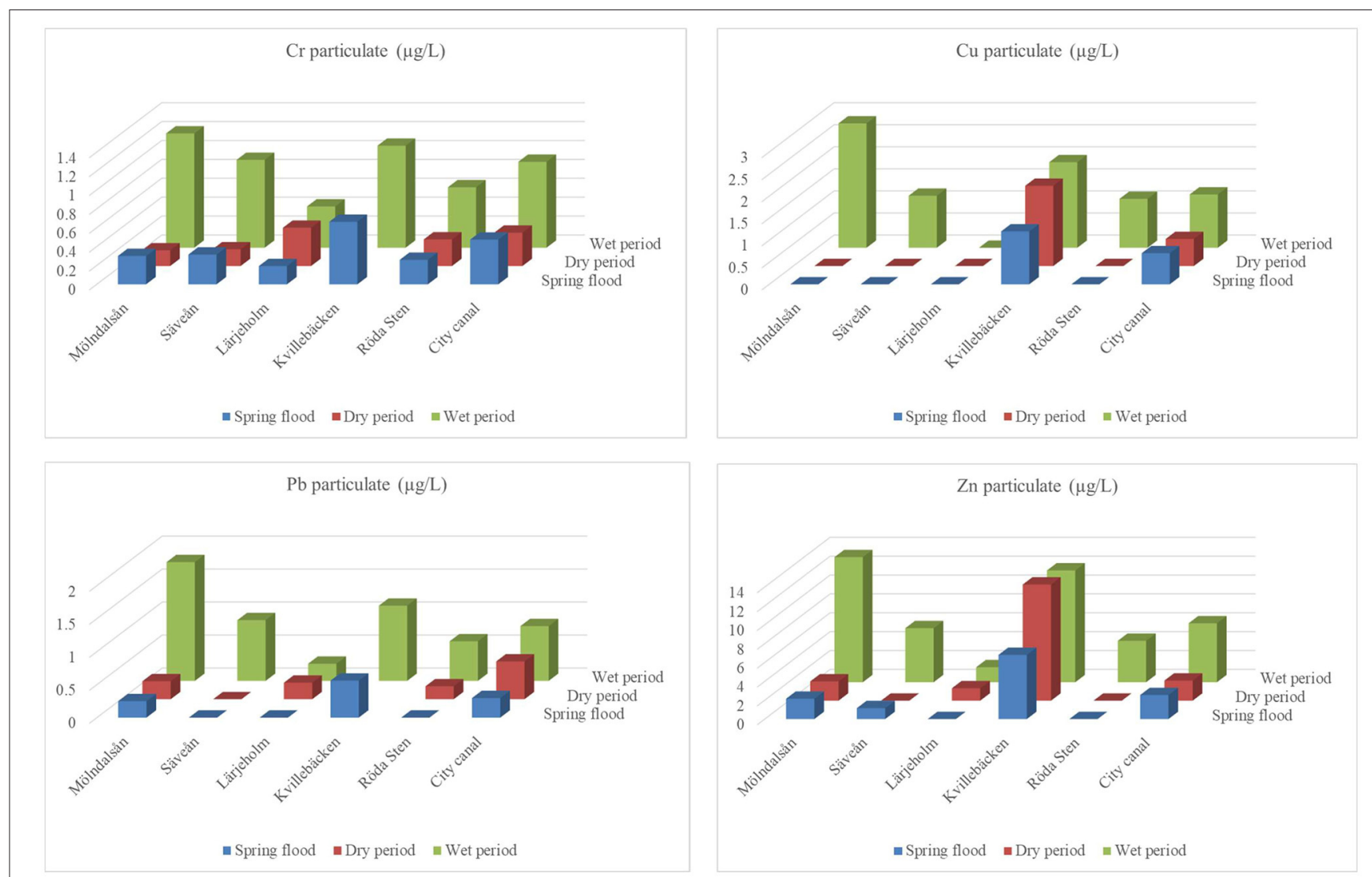

FIGURE 5 | Particulate concentrations of $\mathrm{Cu}, \mathrm{Zn}, \mathrm{Cr}$, and $\mathrm{Pb}$ at sampling sites during the Spring flood, Dry period, and Wet period sampling campaigns.

generally dominated the total content of $\mathrm{Cr}$ and $\mathrm{Pb}$, while $\mathrm{Cu}$ and Zn dominates in the dissolved fraction $(<0.45 \mu \mathrm{m})$ with regard to the total content. In general, the ratio particle bound fraction to the total concentration was largest for the Wet period compared to the two other sampling occasions.

\section{Relation Between Contaminants and Hydrological Parameters}

A correlation analysis (Table 3) show that there is a strong positive and significant correlation between SSC and accumulated $\mathrm{P}$, and that particle bound metals are positively and significantly correlated to SSC and accumulated P (Figure 7). This suggests that run-offs are important for the contaminant transport. We found a negative correlation between discharge and metal concentrations (Figure 7) which suggests that the dispersion pathway most likely is not from eroded re-suspended river material. The correlation to groundwater level is only significant for $\mathrm{Cr}$. The degree of correlation of total metal concentrations to hydrological parameters, as well SSC, is also shown in Figure 7. Although not all correlations to flow, accumulated precipitation and groundwater level are significant for $P<0.05$, the result indicate that there is a variation between the type of metal and how it is correlated to the hydrological parameters.
We found that elevated concentrations of metal contaminants mainly occurred during the Wet period when the ground was more water-saturated. Lowest concentrations of $\mathrm{Zn}$ and $\mathrm{Cu}$ occurred during the Dry period with low ground water levels (GWLs) and low river flows. In contrast, we found lowest concentrations of $\mathrm{Pb}$ and $\mathrm{Cu}$ during the spring flood.

\section{Hydrological Trends}

Analysis of precipitation data for the west coast of Sweden shows that total precipitation has nearly doubled during 1961-2010 (see Figure 8). Except for 1997, there has been a continuous increase in precipitation from the mid-1980s, with an escalation from 2000 (>15\% increase). Analysis of river discharge data shows on an increasing discharge trends for both river Stensjön and Tvärsjön in the Gothenburg areas, although the flow levels differed. The increasing discharge trend for the rivers started at the beginning of the 1980s and coincided with the increasing trend of precipitation. The results are in good agreement with those from SMHI (SMHI is Sweden's national contact point with IPCC). Furthermore, based on 2 year moving averages at three different sites show an increasing trend also of the groundwater level, of between 0.2 and $0.3 \mathrm{~m}$ from 1971 to 2011 (with the major part of the yearly increase during the summer months). 


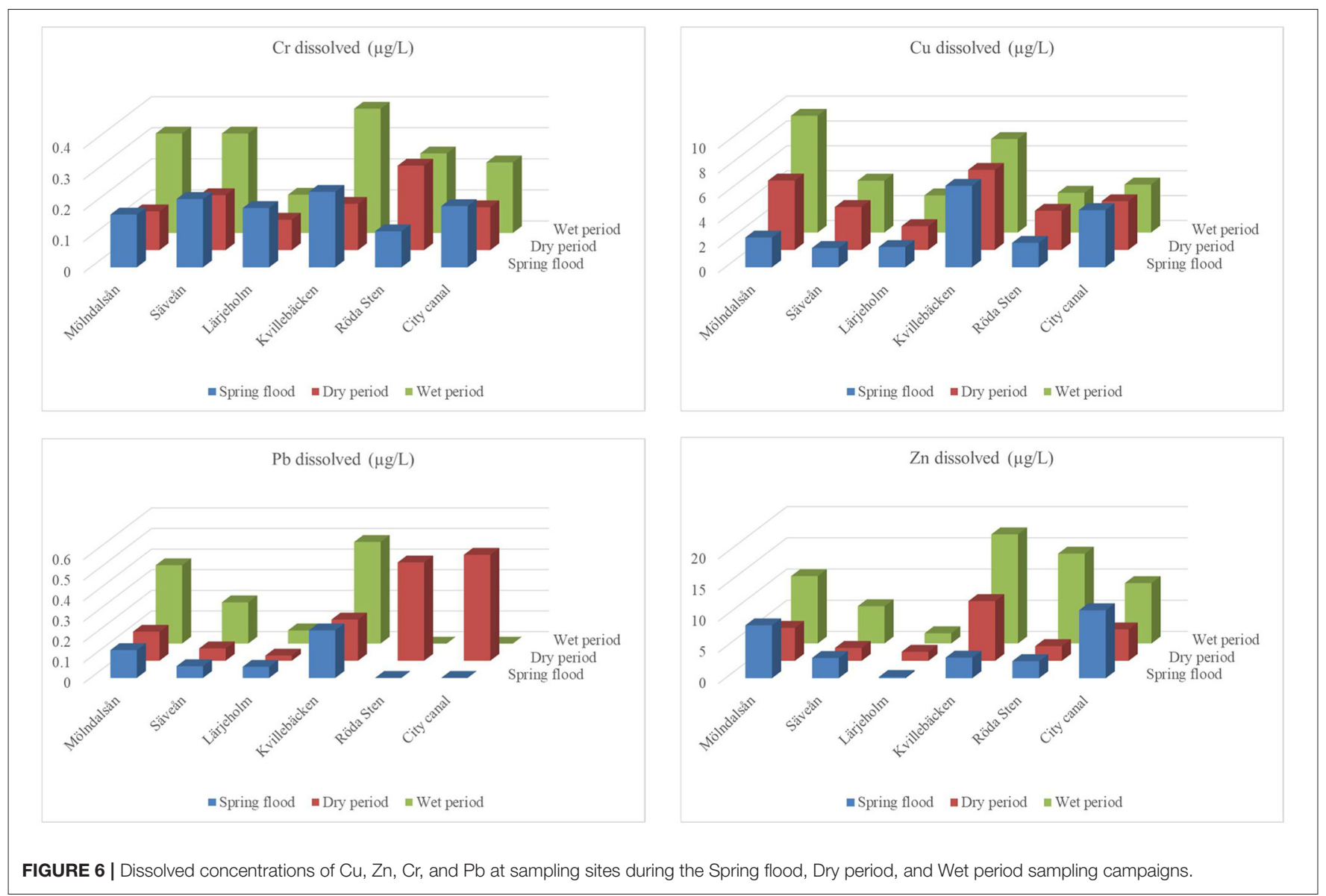

TABLE 3 | Correlation between metal concentrations and physical parameters.

\begin{tabular}{|c|c|c|c|c|c|c|}
\hline & SSC (mg/l) & $Q\left(\mathrm{~m}^{3} / \mathrm{s}\right)$ & $\mathrm{P}(\mathrm{acc}, \mathrm{mm})$ & GWL (m.b.s) & Temp $\left(\mathbf{C}^{\circ}\right)$ & Cond. (mS/cm) \\
\hline SSC (mg/l) & - & -0.16 & 0.80 & 0.39 & 0.61 & -0.80 \\
\hline Zn diss $(\mu / l)$ & 0.49 & -0.46 & 0.51 & 0.46 & 0.18 & -0.15 \\
\hline Zn/Susp ( $\mu \mathrm{gZn/mg} \mathrm{Susp)}$ & 0.26 & -0.74 & 0.28 & 0.27 & 0.14 & -0.43 \\
\hline Cu diss $(\mu / /)$ & 0.60 & -0.55 & 0.39 & 0.07 & 0.48 & -0.15 \\
\hline $\operatorname{Cr} \operatorname{diss}(\mu / l)$ & 0.68 & -0.24 & 0.54 & 0.42 & 0.19 & 0.18 \\
\hline Cr part $(\mu \mathrm{g} / \mathrm{l})$ & 0.94 & -0.33 & 0.82 & 0.56 & 0.44 & -0.20 \\
\hline Cr/Susp ( $\mu$ gCr/mg Susp) & -0.22 & -0.42 & -0.05 & 0.44 & -0.58 & -0.31 \\
\hline $\mathrm{Pb}$ diss $(\mu / /)$ & 0.27 & -0.23 & -0.11 & -0.39 & 0.37 & 0.04 \\
\hline $\mathrm{Pb}$ part $(\mu \mathrm{g} / \mathrm{l})$ & 0.91 & -0.42 & 0.69 & 0.35 & 0.53 & -0.19 \\
\hline
\end{tabular}

Correlations in bold are significant at $P<0.05(N=15)$. Results are shown for suspended sediment concentration $(S S C)$, discharge $(Q)$, accumulated precipitation $(P)$, groundwater level (GWL), temperature (Temp), and electric conductivity (Cond).

\section{DISCUSSION}

\section{Metal Concentrations}

Knowledge about the concentrations of metals in urban waters is important from a public health perspective as long-term exposure of metals in drinking water is associated with an increased risk of mortality and cancer (Wang et al., 2011).

Surface water concentrations of metals are assessed with environmental quality standards (EQS) set in the Swedish EPA report 5799 based on WFD council regulation (EEC, No 793/93). 


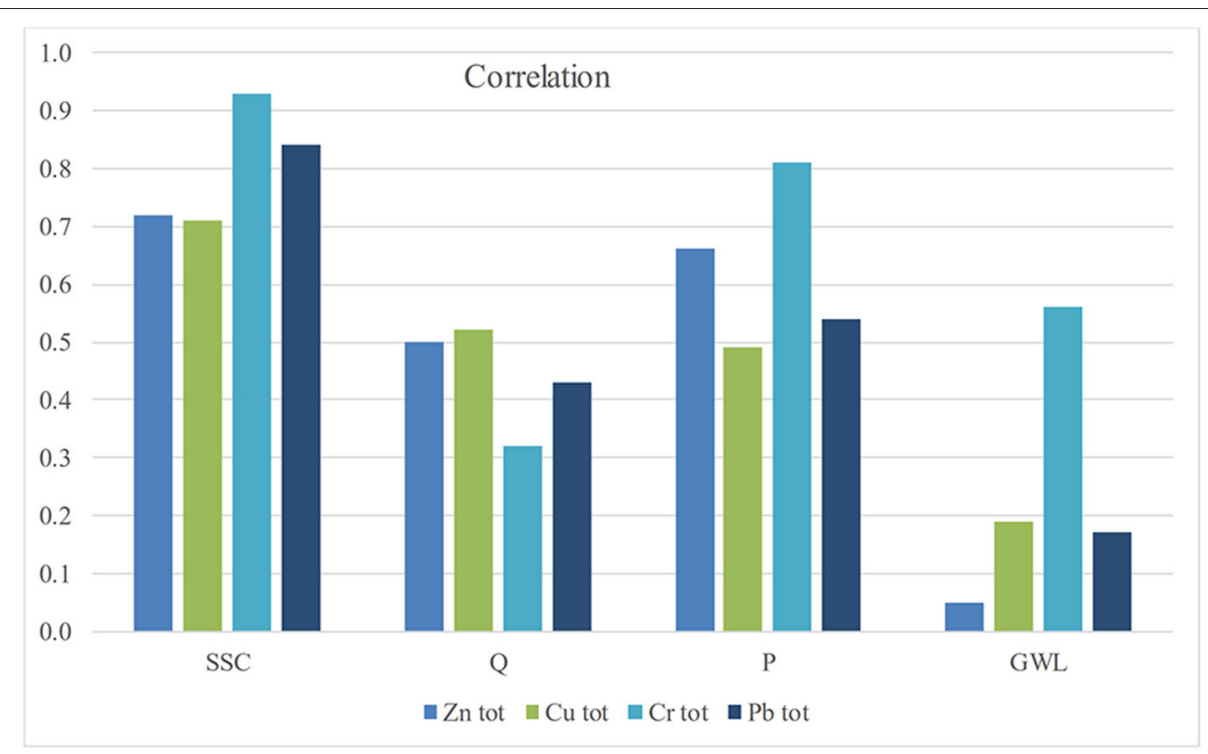

FIGURE 7 | Diagram showing the correlation between metals and suspended sediment concentrations (SSC), discharge (Q), accumulated precipitation (P), and groundwater level (GWL). Correlation to discharge has been normalized to be comparable (the direction of the correlation is otherwise negative).

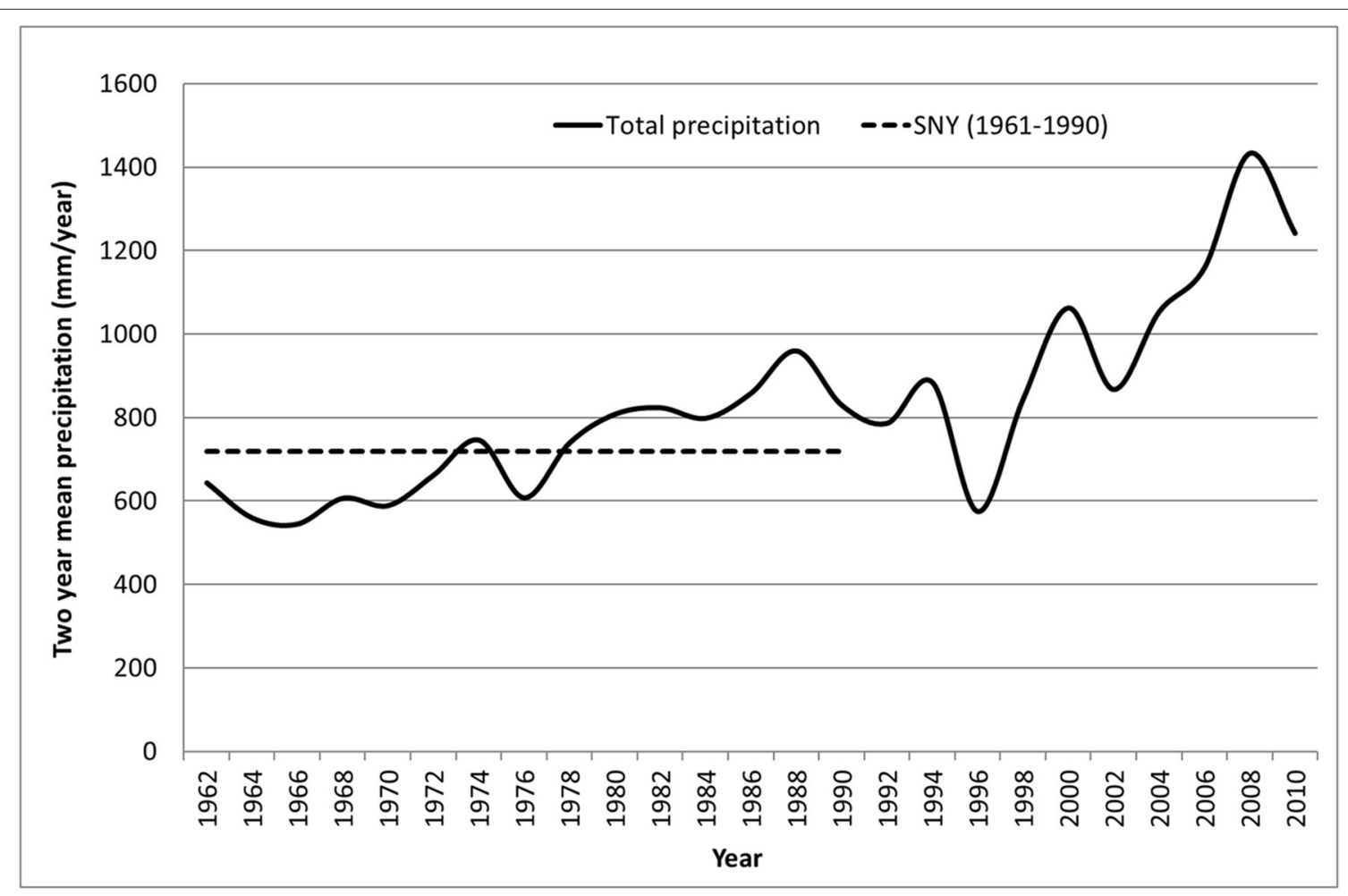

FIGURE 8 | Change in total mean year precipitation in relation to a standard normal year SNY (1961-1990) for Gothenburg area, SW Sweden.

It was found that some of the studied river metals exceeds the EQSs. For example, dissolved concentrations of $\mathrm{Cu}$ and $\mathrm{Zn}$ in river Mölndalsån exceeds the EQS 4 and $3 \mu \mathrm{g} / \mathrm{L}$, respectively. For the river Mölndalsån, a $\mathrm{Cu}$ level of $9.39 \mu \mathrm{g} / \mathrm{L}$ was found for the wet period which is 2.3 times the EQS. Even at low flow (dry period) the EQS was exceeded by 1.4 times. In the river Sävån, the $\mathrm{Cu}$ concentration of $4.18 \mu \mathrm{g} / \mathrm{L}$ for the wet period was found to be just above the EQS. However, the $\mathrm{Cu}$ concentration 
at low flow (dry period) was just below the EQS. For the rivers Mölndalsån and Säveån, $\mathrm{Zn}$ also exceeded the EQS during the wet period by 3.6 and 2.0 times, respectively. The EQS for $\mathrm{Zn}$ was also exceeded during the dry period at river Mölndalsån by 1.8 times but was below the EQS for the Sävån River. On the other hand, at the raw water intake at Lärjeholm, all metal concentrations were found to be lower than the EQSs. This may be due to the fact that the sampling point is located upstream of the city of Gothenburg and thus may be less affected by the urban environment than the sampling point in Mölndalsån River and Säveån River, respectively. However, data from the rivers at Mölndalsån and Sävån may be useful in case more rivers need to be used as water resources for fresh water supply in the future.

For metal contaminants, we found negative correlations to discharge but positive correlations to accumulated precipitation. The very low correlation between discharge and metal contaminants suggests that the main source is likely not from re-suspension of river sediments. In contrast, significant (moderate to strong positive) correlations for $\mathrm{SSC}, \mathrm{Cu}, \mathrm{Cr}, \mathrm{Pb}$, and $\mathrm{Zn}$ with accumulated precipitation, and a strong positive correlation between the metals and SSC, suggests urban surfaces and soils being important sources for these elements. In addition, $\mathrm{Cr}$ also seems to be correlated to groundwater level.

Compared to the spring flood and the dry period, we found a correlation between the Wet period and an increased contaminant transport in the river waters. SSC also increased during the Wet period compared to the other periods but could not be correlated to an increased groundwater level. The SSC in Mölndalsån River and Säveån River were similar, whereas the SSC in River Göta Älv's outlet at Röda Sten, as well as in the City Canal, were comparable. When it comes to Röda Sten and the City canal it may be due to a very high influence from sea water as shown by conductivity measurements (Figure 3). The SSC measured at the different periods upstream the River Göta Älv (Lärjeholm) differed from the relations in SSC between periods found at Mölndalsån River and Sävån River. One explanation could be the strong flow regulation in the River Göta Älv which will level out the effects of river discharge. However, our results show that wet periods bring more contaminants and particles to rivers than dry periods. Our results also indicate that particlebound transport of $\mathrm{Zn}, \mathrm{Cr}$, and $\mathrm{Pb}$ also increases during Wet periods. Based on these results, urban surface runoff and urban groundwater outflow into rivers are suggested to be important dispersion paths ways for contaminants.

Some parameters like $\mathrm{pH}$, redox potential and total organic carbon determines the mobility of contaminants in soils (Appelo and Postma, 1996). A variation in these parameters is to a large extent governed by the groundwater level and its fluctuation (Appelo and Postma, 1996; Augustsson, 2011). Periods with dryer weather cause a fall in groundwater and surface water levels and yield no surface runoff, while rainy periods increase both groundwater and surface water levels and increases surface runoff. An elevated water level or a largely fluctuating water table may increase the leakage of soil contaminants to the water phase (due to the equilibrium process between two phases in contact) as more soil is exposed to water. Furthermore, a raised groundwater table may increase groundwater transport of colloidal bound substances as the groundwater flow increases. On the other hand, a wetter period and a larger volume of water normally is associated with dilution effects to such an extent that a negative correlation is found between discharge and contaminant concentrations. Furthermore, an increased river flow may influence the river bed- and bank erosion which is supposed to re-mobilize contaminants stored in sediments. However, in our case, resuspension of river banks and beds are not suggested as likely important as the contribution from surface runoff. In addition to surface runoff, sewage overflow during heavy rains have shown to bring more contaminants to the rivers in the area (see e.g., Åström et al., 2007).

Dissolved contaminants are usually concentrated close to the groundwater table in soils. As the water table fluctuates with seasonal variations such as during drought or flood conditions, contaminants concentrate in smear zones above and below the mean water table. When a rainfall event is heavy or when it continues for longer periods, the mean groundwater level rise and a surface runoff is created that does not infiltrate the soil again but ends up in river systems (Tu, 2009). Thus, contaminants in pore water and soils may follow the runoff to streams and rivers, which may possibly explain the increased contaminant content found in our analyses from the Wet period. The strong and significant correlation of metal contaminants to SSC is an indication that metal-enriched suspended particles are transported in rivers during rainier periods and further implies that variations in SSC may be used as an indicator for particlebound contaminant transport.

The overall results of metal analyses for three hydrological events Spring flood, Dry period, and Wet period support earlier studies that demonstrate increased metal concentrations during higher discharge (Benítez-Gilabert et al., 2010; Visser et al., 2012; Fan and Shibata, 2015).

\section{Climate Trend in Gothenburg}

In the Gothenburg area, precipitation has increased since the 1980 s and the National calculations for the Swedish west coast predict a continuing increase of precipitation (SMHI, 2020). Our findings suggest that there has also been an increase in groundwater level and discharge during the last decades in Gothenburg due to the increased precipitation. It is thus likely that not only precipitation but also discharge and groundwater level will continue to increase according to future climate change scenarios of precipitation in the region. This will have implications for the mobilization and dispersion of contaminant from adjacent land surfaces and soils to rivers.

The lowest river discharge and groundwater level was found for the Dry period with lowest precipitation, except for the River Göta Älv upstream of Gothenburg City that had its lowest discharge during the Wet period. It is due to the flow regulations at three hydropower stations from Lake Vänern and downstream that regulates the flow depending on the energy demand. The highest river discharge was found during the Spring flood, but the highest groundwater level was instead linked to the Wet period, possibly due to highest accumulated precipitation for this period. Except for the regulated River Göta Älv, we found a relation between precipitation, groundwater level and river discharge. 
The increased precipitation has according to our data, caused both a surficial groundwater transport of mainly $\mathrm{Zn}$ and $\mathrm{Cr}$ and a surface runoff from urban areas of mainly $\mathrm{Cu}$ and $\mathrm{Pb}$ to rivers. This is an indication that rainier periods can bring more contaminants to urban watercourses that consequently in the end may influence drinking water quality. To estimate the possible impact that change in surface runoff may have on metal loads to the River Göta Älv, the study was supplemented with a basic calculation of storm water load (waste water overflow not considered) from housing in urban areas, industrial areas, main roads, forests, and arable land upstream of sampling site Lärjeholm (the raw water intake for drinking water supply), taking into account today's average rainfall and an increase of 20 and $30 \%$, respectively. Based on the calculations, $a+20 \%$ change in precipitation increases the metal load from surface runoff to the river upstream Lärjeholm by as much as $17 \%$, while a $+30 \%$ change in precipitation causes a $23 \%$ increase of surface runoff induced metal load. This calculation is based on that the leaching of metals is constant and does not decrease over time, which cannot be expected over a longer time perspective. In any case, even if the calculations may be exaggerated, the relation to an increased amount of rain is interesting.

Our study suggests that conditions during the wet periods (long lasting rainy periods, increased surface runoffs and leveled groundwater tables) bring more particles and thus contaminants to the rivers in the case study area. This is sought to happen through surface runoff and surficial groundwater flow that transport particles and metal contaminants from the surroundings to the rivers, rather than through erosion or resuspension of river sediments from increased discharge (even though that dispersion paths also exists).

This study explains the main pathways for transport of the metal contaminants under study during different climatological events and the importance of future planning that takes the wetter climate forecast in future into account. Even if the result in our study cannot be used to quantify future loads of contaminants in the river system and watercourses, the strength is that it can give an indication of the on-going processes and thus the future risk so that measures, particularly in areas with much contaminated soils, can be taken. This is also especially important to secure safe drinking water for rapidly urbanizing areas in countries that are challenged by rapid demographic changes and the emerging trend of mega-cities.

\section{REFERENCES}

Åström, J., and Pettersson, T. J. R., Stenström, T.A. (2007). Identification and management of microbial contaminations in a surface drinking water source. J. Water Health 05, 67-79. doi: 10.2166/wh.2007.137

Appelo, C. A. J., and Postma, D. (1996). Geochemistry, Groundwater and Pollution, 2nd Edn, ed A. A. Balkema (Rotterdam: Routledge Taylor and Francis Group).

Astaraie-Imani, M., Kapelan, Z., Fu, G., and Butler, D. (2012). Assessing the combined effects of urbanisation and climate change on the river water quality in an integrated urban wastewater system in the UK. J. Environ. Manage. 112, 1-9. doi: 10.1016/j.jenvman.2012.06.039

Augustsson, A. (2011). Climate Change and Metal Mobility in an Environmental Risk Perspective. Kalmar: Linnaeus University.

\section{CONCLUSIONS}

We found a correlation between a short-term increase in precipitation and an increase in suspended sediment concentration but also an increase in metal contaminant transport in rivers of Gothenburg. Our study suggests that conditions during long lasting rainy periods (that results in high GWLs and increased surface runoff) bring more particles and metal contaminants to rivers than if only river erosion from high discharges would be included. It is known that the first flush from a rain event instantaneously causes peak concentrations in surface waters, but this study indicates that contaminant levels can be high even after the first flush if the rain continues. This seems to happen through surficial groundwater flows and surface runoff in urban areas that transport contaminants from the surroundings. The study also confirms that suspended sediment concentrations can be used a good indicator for variations in particle-bound contaminant transport. The results thus indicate that the prevailing hydrological conditions at and before a sampling occasion are important for the result, which should be kept in mind when designing sampling programs on which assessments and decisions should be based.

\section{DATA AVAILABILITY STATEMENT}

The raw data supporting the conclusions of this article will be made available by the authors, without undue reservation.

\section{AUTHOR CONTRIBUTIONS}

PF-K initiated the concept. GG contributed to the article and has been responsible for the sampling. $\mathrm{MH}$-E contributed to the article and has been responsible for climate data. All authors contributed to the article and approved the submitted version.

\section{FUNDING}

This study was a continuation of the Interreg IVB North Sea Regional Programme DiPol project and was partly funded by the European Regional Developmental Fund Interreg North Sea Region Programme [grant number J-No 35-2-51-08], the Swedish Geotechnical Institute and the IVL Swedish Environmental Research Institute.

Bae, H.-K. (2013). Changes of River's water quality responded to rainfall events. Environ. Ecol. Res. 1, 21-25. doi: 10.13189/eer.2013.010103

Benítez-Gilabert, M., Alvarez-Cobelas, M., and Angeler, D. G. (2010). Effects of climatic change on stream water quality in Spain. Clim. Chang. 103, 339-352. doi: 10.1007/s10584-009-9778-9

Boehlert, B., Strzepek, K. M., Chapra, S. C., Fant, C., Gebretsadik, Y., Lickley, M., et al. (2015). Climate change impacts and greenhouse gas mitigation effects on U. S. water quality. J. Adv. Model Earth Syst. 7, 1326-1338. doi: 10.1002/2014MS000400

Chowdhury, S., Jafar Mazumder, M. A., Al-Attas, O., and Husain, T. (2016). Heavy metals in drinking water: occurrences, implications, and future needs in developing countries. Sci. Total Environ. 569, 476-488. doi: 10.1016/j.scitotenv.2016.06.166 
Christensen, J. H., Larsen, M. A. D., Christensen, O. B., Drews, M., and Stendel, M. (2019). Robustness of European climate projections from dynamical downscaling. Clim. Dyn. 53, 4857-4869. doi: 10.1007/s00382-01904831-z

Crossman, J., Futter, M. N., Oni, S. K., Whitehead, P. G., Jin, L., Butterfield, D., et al. (2013). Impacts of climate change on hydrology and water quality: future proofing management strategies in the Lake Simcoe watershed. Canada J. Great Lake Res. 39, 19-32. doi: 10.1016/j.jglr.2012.11.003

Dankers, R., and Feyen, L. (2009). Flood hazard in Europe in an ensemble of regional climate scenarios. J. Geophys. Res. 114:D16. doi: 10.1029/2008JD011523

EPA (1994). Method 200.8: Determination of Trace Elements in Waters and Wastes by Inductively Coupled Plasma-Mass Spectrometry. Available online at: https:// www.epa.gov/esam/epa-method-2008-determination-trace-elements-waters-a nd-wastes-inductively-coupled-plasma-mass (accessed October 15, 2020).

EPA (1997). Method 200.7: Determination of Metals and Trace Elements in Water and Wastes by Inductively Coupled Plasma-Atomic Emission Spectrometry. Available online at: https:/www.epa.gov/esam/method-2007-determinat ion-metals-and-trace-elements-water-and-wastes-inductively-coupled-plasma (accessed October 15, 2020).

Fan, M., and Shibata, H. (2015). Simulation of watershed hydrology and stream water quality under land use and climate change scenarios in Teshio River watershed, Northern Japan. Ecol. Indic. 50, 79-89. doi: 10.1016/j.ecolind.2014.11.003

Frogner, P. (1998). Dissolution mechanisms of albite and hornblende and of calcite in sandstone, PhD-Dissertation, Department of Geology and Geochemistry, Stockholm University.

Frogner, P., Gislason, S. R., and Oskarsson, N. (2001). Fertilizing potential of volcanic ash in ocean surface water. Geology 29, 487-490. doi: 10.1130/0091-7613(2001)029<0487:FPOVAI >2.0.CO;2

Göransson, G., Larson, M., and Bendz, D. (2013). Variation in turbidity with precipitation and flow in a regulated river system - river Göta Älv, SW Sweden. HESS 17, 2529-2542. doi: 10.5194/hess-17-2529-2013

Göta älvs vattenvårdsförbund (2010). Vattendragskontroll. Del A Göta älv. Del B Säveån. Del C Mölndalsån. Available online at: https://www.gotaalvvvf.org/ rapporter/2010.4.101b298612d0e33932680001803.html (accessed October 20, 2020).

Hurrell, J. W., Kushnir, Y., Ottersen, G., and Visbeck, M. (eds.) (2003). An overview of the North Atlantic Oscillation. The North Atlantic Oscillation: Climatic Significance and Environmental Impact. in Geophysical Monograph Series, Vol.134. p. 1-35. Available online at: https://agupubs.onlinelibrary.wiley. com/doi/book/10.1029/GM134

Islam, S., Ahmed, K., Raknuzzamanb, M., Mamunb, H., and Islam, M. K. (2015). Heavy metal pollution in surface water and sediment: a preliminary assessment of an urban river in a developing country. Ecol. Indic. 48, 282-291. doi: 10.1016/j.ecolind.2014.08.016

Keeling, C. D., and Whorf, T. P. (1999). "Atmospheric CO2 records from sites in the SIO air sampling network," in Trends; A Compendium of Data on Global Change (Oak Ridge, TN: Carbon Dioxide Information Analysis Center, Oak Ridge National Laboratory).

Khan, S. J., Deere, D., Leusch, F. D. L., Humpage, A., Jenkins, M., and Cunliffe, D. (2015). Extreme weather events: should drinking water quality management systems adapt to changing risk profiles? Water Res. 85, 124-136. doi: 10.1016/j.watres.2015.08.018

Kløve, B., Ala-Aho, P., Bertrand, G., Gurdak, J. J., Kupfersberger, H., Kværner, J., et al. (2014). Climate change impacts on groundwater and dependent ecosystems. J. Hydrol. 518, 250-266. doi: 10.1016/j.jhydrol.2013. 06.037

Larsen, T. A., Hoffmann, S., Lüthi, C., Truffer, B., and Maurer, M. (2016). Emerging solutions to the water challenges of an urbanizing world. Science 352, 928-933. doi: $10.1126 /$ science.aad8641

Lerner, D. N., and Harris, B. (2009). The relationship between land use and groundwater resources and quality. Land Use Policy 26, 265-273. doi: 10.1016/j.landusepol.2009.09.005

McDonald, R. E. (2011). Understanding the impact of climate change on Northern Hemisphere extra-tropical cyclones. Clim. Dyn. 37, 1399-1425. doi: 10.1007/s00382-010-0916-x
Mouri, G., Shinoda, S., Golosov, V., Shiiba, M., Hori, T., Kanae, S., et al. (2012). Ecological and hydrological responses to climate change in an urban-forested catchment, Nagara River basin. Japan. Urban Clim. 1, 40-54. doi: 10.1016/j.uclim.2012.08.002

Navarro, A., and Cabonell, M. (2007). Evaluation of groundwater contamination beneath an urban environment: the Besòs river basin (Barcelona, Spain). JEMA 85, 259-269. doi: 10.1016/j.jenvman.2006.08.021

Pall, P., Aina, T., Stone, D. P., Stott, P. A., Nozawa, T., Hilberts, A. G. J., et al. (2011). Anthropogenic greenhouse gas contribution to flood risk in England and wales in autumn 2000. Nature 470, 382-385. doi: 10.1038/nature 09762

Prathumratana, L., Sthiannopkao, S., and Kim, K. W. (2011). The relationship of climatic and hydrological parameters to surface water quality in the lower Mekong River, Review article. Environ. Int. 34, 860-866. doi: 10.1016/j.envint.2007.10.011

Rajczak, J., and Schär, C. (2017). Projections of future precipitation extremes over Europe: a multi-model assessment of climate simulations. J. Geophys. Res. Atmos. 122, 10,773-10,800. doi: 10.1002/2017 JD027176

Rivett, M. O., Ellis, P. A., and Mackay, R. (2011). Urban groundwater base flow influence upon inorganic river-water quality: the River Tame headwaters catchment in the City of Birmingham, UK. J. Hydrol. 400, 206-222. doi: 10.1016/j.jhydrol.2011.01.036

Rostami, S., He, J., and Hassan, Q. K. (2018). Riverine water quality response to precipitation and its change. Environments 5:8. doi: 10.3390/environments5010008

Sangel de Oliviera, B. S., and Cavalcanti de Cunha, A. (2014). Correlation between water quality and precipitation variability in the Southern state of Amapá. Ambiente Agua 9, 261-275. doi: 10.4136/ ambi-agua. 1287

Schiermaier, Q. (2011). Increased flood risk linked to global warming. Nature 470:316. doi: 10.1038/470316a

Semadevi-Davies, A., Hernebring, C., Svensson, G., and Gustafsson, L. G. (2008). The impacts of climate change and urbanisation on drainage in Helsingborg, Sweden: combined sewer system. J. Hydrol. 350, 100-113. doi: 10.1016/j.jhydrol.2007.05.028

SMHI (2020). Swedish Meteorological and Hydrological Institute. Climate Scenarios. Available online at: https:/www.smhi.se/en/climate/climatescenarios/ (accessed June 24, 2020).

Tu, J. (2009). Combined impact of climate and land use changes on streamflow and water quality in eastern Massachusetts, USA. J. Hydrol. 379, 268-283. doi: 10.1016/j.jhydrol.2009.10.009

Ulbrich, U., Leckebusch, G. C., and Pinto, J. G. (2009). Extra-tropical cyclones in the present and future climate: a review. Theor. Appl. Climatol. 96, 117-131. doi: 10.1007/s00704-008-0083-8

Visser, A., Kroes, J., van Vliet, M. T. H., Blenkinsop, S., Fowler, H. J., and Broers, H. P. (2012). Climate change impacts on the leaching of a heavy metal contamination in a small lowland catchment. J Contam. Hydrol. 127, 47-64. doi: 10.1016/j.jconhyd.2011.04.007

Wang, D., Lin, W., Yang, X., Zhai, W., Dai, M., and Chen, C. T. A. (2012) Occurrences of dissolved trace metals $(\mathrm{Cu}, \mathrm{Cd}$ and $\mathrm{Mn}$ ) in the Pearl River Estuary (China), a large river-groundwater-estuary system. Cont. Shelf Res. 50-51, 54-63. doi: 10.1016/j.csr.2012.10.009

Wang, D., Xu, Y., Pan, S., and Ling, W. (2011). Long-term heavy metal pollution and mortality in a Chinese population: an ecologic study. Biol. Trace Elem. Res. 142, 362-379. doi: 10.1007/s12011-010-8802-2

Whitehead, P. G., Wilby, R. L., Battarbee, R. W., Kernan, M., and Wade, A. J. (2009). A review of the potential impacts of climate change on surface water quality. Hydrol. Sci. J. 54, 101-123. doi: 10.1623/hysj. 54.1.101

Wilson, C. O., and Weng, Q. (2011). Simulating the impact of future land use and climate changes on surface water quality in the Des Plaines River watershed, Chicago Metropolitan Statistical Area, Illinois. Sci. Total Environ. 409, 4387-4405. doi: 10.1016/j.scitotenv.2011.07.001

World Health Organization (2020). World Health Organization, Priority Environment and Health Risks. Available online at: http://www.who.int/heli/ risks/en/ (accessed June 24, 2020). 
Xia, X. H., Wu, Q., Mou, X. L., and Lai, Y. J. (2015). Potential impacts of climate change on the water quality of different water bodies. J. Environ. Inform. 25, 85-98. doi: 10.3808/jei.201400263

Conflict of Interest: The authors declare that the research was conducted in the absence of any commercial or financial relationships that could be construed as a potential conflict of interest.
Copyright (C) 2020 Frogner-Kockum, Göransson and Haeger-Eugensson. This is an open-access article distributed under the terms of the Creative Commons Attribution License (CC BY). The use, distribution or reproduction in other forums is permitted, provided the original author(s) and the copyright owner(s) are credited and that the original publication in this journal is cited, in accordance with accepted academic practice. No use, distribution or reproduction is permitted which does not comply with these terms. 